|||||||||||||||||||||||||||||||||||||

\title{
研究論文
}

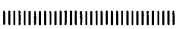

\section{各種アルミニウム合金の切削過程に及ぼす 構成刃先の影響}

\author{
山田 茂* ·水谷 秀行** \\ 能登谷久公* . 高柳晃 $* * *$
}

\begin{abstract}
Effects of built-up edge on cutting process of
various aluminum alloys
\end{abstract}

\author{
Shigeru YAMADA*, Hideyuki MIZUTANI** \\ Hisakimi NOTOYA* and Akira TAKAYANAGI***
}

\begin{abstract}
The built-up edge in machining of an aluminum alloy is an important problem, and its shape affects the cutting state of the alloy. The aim of this study is to elucidate the main cause of the shape change of the built-up edge. The effect of the shape of the built-up edge on the cutting process was also investigated. The shape of the built-up edge can be roughly classified into two types: the wedge type and nose type. The machining of $\mathrm{Al}-\mathrm{Mg}$ alloys results in the formation of the wedge type built-up edge which remains on the tool face. The addition of $\mathrm{Si}$ or $\mathrm{Bi}$ to a work material of an aluminum results in the formation of the nose type built-up edge. The wedge type built-up edge was observed in machining of alloys with high hardness and high work hardenability. While the cutting force, surface roughness and affected-layer depth decrease in the case of the wedge type built-up edge, these values increase in the case of the nose type built-up edge.
\end{abstract}

Keywords: built-up edge, aluminum alloy, properties of work material, cutting force, surface roughness

(Received October 1, 1992)

\section{1. 緒言}

近年, 工作機械や工具材料の発達によって切削速度の 高速化が図られ，構成刃先の問題はあまり重要視されな い傾向にあるが，小径の穴加工やタップ作業などにおい ては低速切削を余儀なくされる場合も多く，その影響は 無視できない。アルミニウム合金の切削には，耐摩耗性 に優れたダイヤモンド工具が普及しつつあるが工具形状 の創成が容易でュスト的にも有利な高速度鋼工具が使用 される場合も多い1。この場合に発生する構成刃先は, 切削抵抗や仕上げ面粗さなど切削過程に及ぼす影響も大
きい。また，切削加工の際に発生する構成刃先の功罪に ついてはこれまでにも検討されているが，その形状の差 異を決定する要因について詳細に論じたものはあまりみ られない。

本報告では, 各種アルミニウム合金切削の際に生じる 構成刃先の形状について, その支配要因を被削材の化学 組成および機械的性質の観点から検討し，併せて切りく ず生成, 切削抵抗，仕上げ面粗さおよび加工変質層など に及ぼす構成刃先の形状の影響について検討するもので ある。

* 富山大学工学部機械システム工学科 (富山市)。Mechanical System Engineering, Fuculty of Engineering, Toyama University (Toyama-shi, Toyama).

** 中部大学工学部機械工学科 (春日井市)。Mechanical Engineering, College of Engineering, Chubu University (Kasugai-shi, Aichi).

*** 東海ゴム工業(㑣)(小牧市)。Tokai Rubber Industries, Ltd. (Komaki-shi, Aichi). 


\section{2. 実験用材料，装置および実験方法}

本研究では，鋳造材としては金型鋳造したAC5A ア ルミニウム合金を，また展伸材としては耐食性の優れた 5056 アルミニウム合金と高張力の7075アルミニウム合金 を使用した。非熱処理型合金として，被削性の向上を図 った $\mathrm{Al}-\mathrm{Mn}-\mathrm{Si}$ 系合金と $\mathrm{Al}-\mathrm{Mn}-\mathrm{Mg}$ 系合金 ${ }^{2)}$ を使用し た。非熱処理型合金についてはシリコンやマグネシウム 量を変えたり，ビスマスを添加して材料特性の変化を図 ったものである。供試材は，化学組成以外に熱処理など によってその性質を变化させた。その状態を Table 1 の 実験用材料の化学組成の表中に調質記号を用いて示し た。また，それらの機械的性質は Table 2 に示すとおり であり, 被削材硬さの増大は引張強さおよび耐力の増大 を意味する。一方，伸びは硬さの増大によって減少する 傾向にある。

実験は, まず二次元切削により, 切削過程における諸 現象の変化を詳細に調べることにした。切りくず生成お よび構成刃先の生成状態については切削急停止装置 ${ }^{3)}$ 用いて切削点の観察を行った。加工変質層については, マイクロビッカース硬度計によって測定した加工面の深 さ方向の硬さ分布より加工硬化層深さ $\mathrm{y}_{\mathrm{H}}$ を求めた。切 削抵抗は，ひずみゲージ方式の工具動力計により主分力 $\mathrm{Q}$ と背分力 $\mathrm{P}$ とを測定した。二次元切削の際の実験条 件は, 切削工具: 材種 $\cdot$ SKH4A, 寸くい角 $\gamma=\pi / 18$

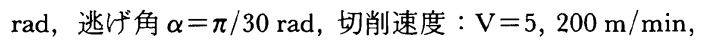

切込み: $t_{1}=0.05 \mathrm{~mm}$, 切削幅 : b = $1.0 \mathrm{~mm}$, 切削油 剂：なし（乾式）である。

一方，仕上げ面粗さについては，一般的な切削方法で ある長手送り旋削実験を行い, 工作物軸方向の断面プロ フィルを触針式表面形状測定器により測定し, 十点平均 粗さ $\mathrm{R}_{\mathrm{z}}$ を求めて検討した。長手送り旋削実験条件は次 のとおりである。切削工具：材種·SKH4A，工具諸元 $\cdot 0-\pi / 18-\pi / 30-\pi / 30-\pi / 30-0-0$, 切削速度: $\mathrm{V}=5 \mathrm{~m} /$ $\min$, 切込み: $\mathrm{a}=0.5 \mathrm{~mm}$, 工具送り $: \mathrm{S}=0.15 \mathrm{~mm} / \mathrm{rev}$, 切削油剤：なし(乾式)。

\section{3. 実験結果およびその検討}

\section{1 構成刃先形状に及ぼす被削材の化学組成, 機械 的性質および加工硬化性の影響}

各種アルミニウム合金の切削における構成刃先の生成 状態を切削急停止装置を用いて調べた結果, 7075-T6 合 金（試料 $\mathrm{C）} \mathrm{中には} \mathrm{Mg}_{2} \mathrm{Si}, \mathrm{CuAl}_{2}, \mathrm{FeAl}_{3}$ などの硬い金 属間化合物が含まれるため，切削に際してこれら硬質粒 子の引掻き作用によって構成刃先の生成が抑制されると 推察され，これを認めなかったが，その他の材料では明 瞭な構成刃先の生成が認められた。構成刃先の形状を大 別すると鼻形とくさび形とに分けられ，それらの典型的 な観察例を Fig. 1 に示す。図中 (a)，(b)に示すくさび形 構成刃先の場合, 切りくずと構成刃先との境界が比較的 明瞭ですくい角増大現象が認められる。

一方, 同図 (c), (d) に示す鼻型構成刃先の場合には切

Table 1 Chemical compositions of specimens (mass\%)

\begin{tabular}{|c|c|c|c|c|c|c|c|c|c|c|c|c|c|c|c|c|}
\hline \multicolumn{4}{|c|}{ Material } & \multirow[b]{2}{*}{$\mathrm{Si}$} & \multirow[b]{2}{*}{$\mathrm{Fe}$} & \multirow[b]{2}{*}{$\mathrm{Cu}$} & \multirow[b]{2}{*}{$\mathrm{Mn}$} & \multirow[b]{2}{*}{$\mathrm{Mg}$} & \multirow[b]{2}{*}{$\mathrm{Cr}$} & \multirow[b]{2}{*}{$\mathrm{Zn}$} & \multirow[b]{2}{*}{$\mathrm{Ti}$} & \multirow[b]{2}{*}{$\mathrm{Ni}$} & \multirow[b]{2}{*}{$\mathrm{Pb}$} & \multirow[b]{2}{*}{$\mathrm{Sn}$} & \multirow[b]{2}{*}{$\mathrm{Bi}$} & \multirow[b]{2}{*}{$\mathrm{Al}$} \\
\hline Syn & abol & Alloy & $\begin{array}{l}\text { Treat- } \\
\text { ment }\end{array}$ & & & & & & & & & & & & & \\
\hline \multicolumn{2}{|c|}{ A } & AC5A & $\mathrm{T} 6$ & 0.06 & 0.14 & 4.42 & - & 1.74 & - & 0.02 & 0.01 & 2.24 & - & - & - & bal \\
\hline \multicolumn{2}{|c|}{$\mathrm{B}$} & 5056 & H112 & 0.07 & 0.18 & $\operatorname{Tr}$ & 0.05 & 4.47 & 0.05 & $\operatorname{Tr}$ & 0.01 & - & - & - & - & bal \\
\hline \multicolumn{2}{|c|}{$\mathrm{C}$} & 7075 & T6 & 0.50 & 0.70 & 1.60 & 0.30 & 2.10 & - & 5.60 & 0.20 & - & - & - & - & bal \\
\hline D & $\begin{array}{l}\mathrm{D}_{1} \\
\mathrm{D}_{2}\end{array}$ & \multirow{3}{*}{$\begin{array}{l}\text { Free cutting } \\
\mathrm{Al}-\mathrm{Mn}-\mathrm{Si} \\
\text { alloy }\end{array}$} & $\begin{array}{c}\mathrm{H} 34 \\
\mathrm{O}\end{array}$ & 0.09 & 0.33 & - & 0.94 & $<0.01$ & - & 0.95 & - & - & 0.42 & 0.51 & - & bal \\
\hline $\mathrm{E}$ & $\begin{array}{l}\mathrm{E}_{1} \\
\mathrm{E}_{2}\end{array}$ & & $\begin{array}{c}\mathrm{H} 34 \\
\mathrm{O}\end{array}$ & 1.51 & 0.32 & - & 0.95 & $<0.01$ & - & 0.99 & - & - & 0.46 & 0.50 & - & bal \\
\hline \multicolumn{2}{|c|}{$\mathrm{F}$} & & $\mathrm{H} 34$ & 1.55 & 0.34 & - & 1.41 & $<0.01$ & - & 0.10 & - & - & 0.54 & 0.50 & 0.30 & bal \\
\hline $\mathrm{G}$ & $\begin{array}{l}G_{1} \\
G_{2}\end{array}$ & \multirow{3}{*}{$\begin{array}{c}\text { Free cutting } \\
\mathrm{Al}-\mathrm{Mn}-\mathrm{Mg} \\
\text { alloy }\end{array}$} & $\begin{array}{c}\mathrm{H} 34 \\
\mathrm{O}\end{array}$ & 0.10 & 0.33 & - & 1.44 & 1.05 & - & 0.11 & - & - & 0.50 & 0.52 & - & bal \\
\hline $\mathrm{H}$ & $\begin{array}{l}\mathrm{H}_{1} \\
\mathrm{H}_{2}\end{array}$ & & $\begin{array}{c}\mathrm{H} 34 \\
\mathrm{O}\end{array}$ & 0.10 & 0.32 & - & 1.46 & 2.03 & - & 0.13 & - & - & 0.42 & 0.52 & - & bal \\
\hline I & $\begin{array}{l}\mathrm{I}_{1} \\
\mathrm{I}_{2}\end{array}$ & & $\begin{array}{c}\mathrm{H} 34 \\
\mathrm{O}\end{array}$ & 0.10 & 0.34 & - & 1.44 & 0.34 & - & 0.10 & - & - & 0.47 & 0.53 & 0.28 & bal \\
\hline
\end{tabular}


Table 2 Mechanical properties of specimens

\begin{tabular}{|c|c|c|c|c|c|c|c|}
\hline \multicolumn{4}{|c|}{ Material } & \multirow{2}{*}{$\begin{array}{l}\text { Tensile } \\
\text { strength } \sigma_{\mathrm{B}} \\
(\mathrm{MPa})\end{array}$} & \multirow{2}{*}{$\begin{array}{l}0.2 \% \text { Yield } \\
\text { strength } \sigma_{0.2} \\
(\mathrm{MPa})\end{array}$} & \multirow{2}{*}{$\begin{array}{c}\text { Elongation } \\
\boldsymbol{\delta} \\
(\%)\end{array}$} & \multirow{2}{*}{$\begin{array}{c}\text { Vickers } \\
\text { hardness } \\
\text { HV }\end{array}$} \\
\hline \multicolumn{2}{|c|}{ Symbol } & Alloy & Treatment & & & & \\
\hline \multicolumn{2}{|c|}{ A } & AC5A & $\mathrm{T} 6$ & 359 & 272 & 1.0 & 130.2 \\
\hline \multicolumn{2}{|c|}{ B } & 5056 & H112 & 224 & 155 & 38.0 & 68.5 \\
\hline \multicolumn{2}{|c|}{$\mathrm{C}$} & 7075 & T6 & 570 & 513 & 11.0 & 188.0 \\
\hline \multirow{2}{*}{ D } & $\mathrm{D}_{1}$ & \multirow{5}{*}{$\begin{array}{c}\text { Free cutting } \\
\text { Al-Mn-Si alloy }\end{array}$} & H34 & 176 & 157 & 23.0 & 50.3 \\
\hline & $\mathrm{D}_{2}$ & & $\mathrm{O}$ & 107 & 39 & 50.3 & 43.7 \\
\hline \multirow{2}{*}{$\mathrm{E}$} & $\mathrm{E}_{1}$ & & $\mathrm{H} 34$ & 176 & 157 & 19.5 & 51.4 \\
\hline & $\mathrm{E}_{2}$ & & $\mathrm{O}$ & 119 & 49 & 47.2 & 45.7 \\
\hline \multicolumn{2}{|c|}{$\mathrm{F}$} & & $\mathrm{H} 34$ & 185 & 166 & 18.1 & 56.0 \\
\hline \multirow{2}{*}{ G } & $\mathrm{G}_{1}$ & \multirow{6}{*}{$\begin{array}{c}\text { Free cutting } \\
\mathrm{Al}-\mathrm{Mn}-\mathrm{Mg} \text { alloy }\end{array}$} & H34 & 243 & 209 & 15.5 & 67.9 \\
\hline & $\mathrm{G}_{2}$ & & $\mathrm{O}$ & 175 & 54 & 32.2 & 52.0 \\
\hline $\mathrm{H}$ & $\mathrm{H}_{1}$ & & H34 & 298 & 245 & 15.3 & 79.2 \\
\hline & $\mathrm{H}_{2}$ & & $\mathrm{O}$ & 230 & 75 & 27.5 & 66.9 \\
\hline \multirow{2}{*}{ I } & $\mathrm{I}_{1}$ & & $\mathrm{H} 34$ & 244 & 208 & 16.5 & 59.2 \\
\hline & $\mathrm{I}_{2}$ & & $\mathrm{O}$ & 133 & 42 & 42.5 & 49.5 \\
\hline
\end{tabular}

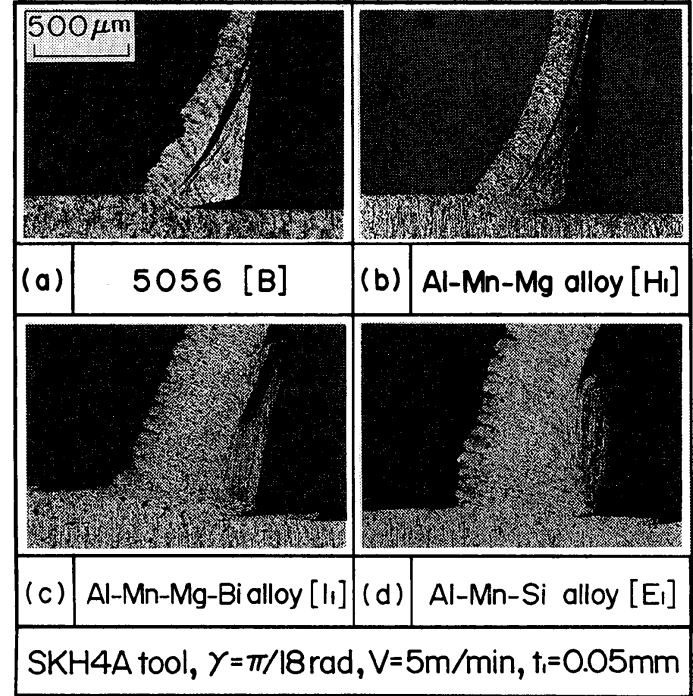

Fig. 1 Observation of chip and built-up edge in orthogonal cutting.

りくずと構成刃先の明瞭な境界は認められず，また，刃 先としての鋭さはみられない。

構成刃先の形状に及ぼす化学組成の影響については, マグネシウムの添加によってくさび形構成刃先，シリコ ンあるいはビスマスの添加によって鼻形の構成刃先が生 成される傾向がみられた。本来，構成刃先とは，ある速 度範囲で金属を切削中に被削材の一部が切削抵抗のため に急激な加工硬化を受け，被削母材よりも著しく硬さの

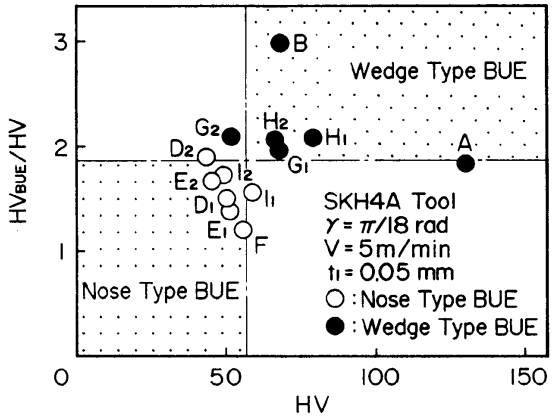

Fig. 2 Influence of work hardness and work hardnability on the shape of built-up edge.

高い変質物となって切削工具すくい面上の先端部に堆積 付着したもので，切削状態に大きな変化をもたらすもの とされている4)。したがって，構成刃先の生成状態は材 料の加工硬化性とも関係があるものとされている。そこ で，母材硬さと加工硬化の関係を検討するため, 横軸に 被削材の硬さをとり，また繸軸に構成刃先の平均硬さ $\mathrm{HV}_{\mathrm{BUE}}$ を被削材硬さ $\mathrm{HV}$ で割った值 $\mathrm{HV}_{\mathrm{BUE}} / \mathrm{HV}$ をと り, 両者の関係と構成刃先の形状の変化を調べた結果は Fig. 2 亿示すとおりである。同図より， $\mathrm{HV}_{\mathrm{BUE}} / \mathrm{HV}$ (以後, 加工硬化率で表す) がある值を境に, それより 高ければくさび形構成刃先, 逆に低ければ鼻形になる傾 向がみられる。被削材硬さについても，ある值を境に硬 さの高い領域ではくさび形，それが低い領域では鼻形に なる傾向がみられる。したがって, 構成刃先形状は被削 


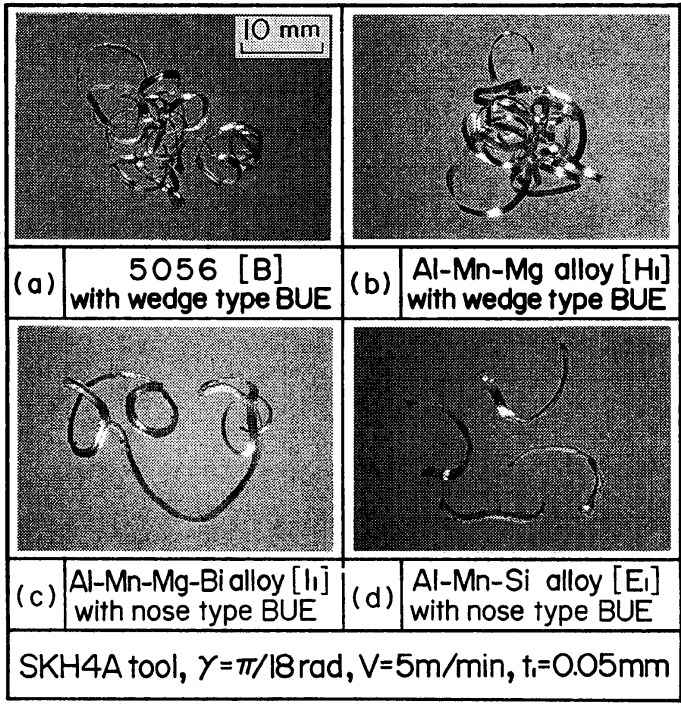

Fig. 3 Influence of built-up edge on chip form.

材硬さおよび加工硬化性の違いによっても支配され，硬 さの值が高く，加工硬化率の高い材料の切削ではくさび 形の構成刃先が生成され，これとは逆の場合には鼻形の 構成刃先が生成されることが明らかとなった。

\section{2 切りくず生成過程に及ぼす構成刃先の影響}

まず，切りくず生成過程について検討すると，前出 Fig. 1 にみられるよらに，構成刃先形状によって切りく ず生成状態が大きく異なることが知られる。すなわち, くさび形の構成刃先を生じた場合の切りくずは，厚さが 小さく表面形態も比較的なめらかである。他方，鼻形構 成刃先が発生すると刃先前方における被削材の滞留が大 きく，切りくず厚さが大となり，切りくずとしての被削 材からの分離, 排出が困難な状況がらかがわれる。ま た，構成刃先生成時の切りくずの例を Fig. 3 に示すが, 図中 (a) および (b) はくさび形構成刃先生成時の切りく ずであり，(c) および (d) は鼻形の場合の切りくずを示す ものである。くさび形構成刃先の昜合には明らかにすく い角増大効果による滑らかな流れ形の切りくずを生成し ている。これに対し，鼻形構成刃先の場合には，〈さび 形の場合に比べてカール半径が大きくなり，回転中の工 作物に接触してカール方向に対して外向きの曲げモーメ ントを受け5)，切断しやすくなる傾向がみられた。ま た，供試試料中の非熱処理型快削アルミニウム合金には 鉛, 錫, ビスマスが添加されているが, これらはアルミ ニウムにはほとんど固溶しないため，合金中では単体の 粒子となって存在する。そして，鉛，錫，ビスマスは非 常に軟らかく，せん断域において薄く延ばされやすく， しかも低融点であるため，合金中にこれらの粒子が存在
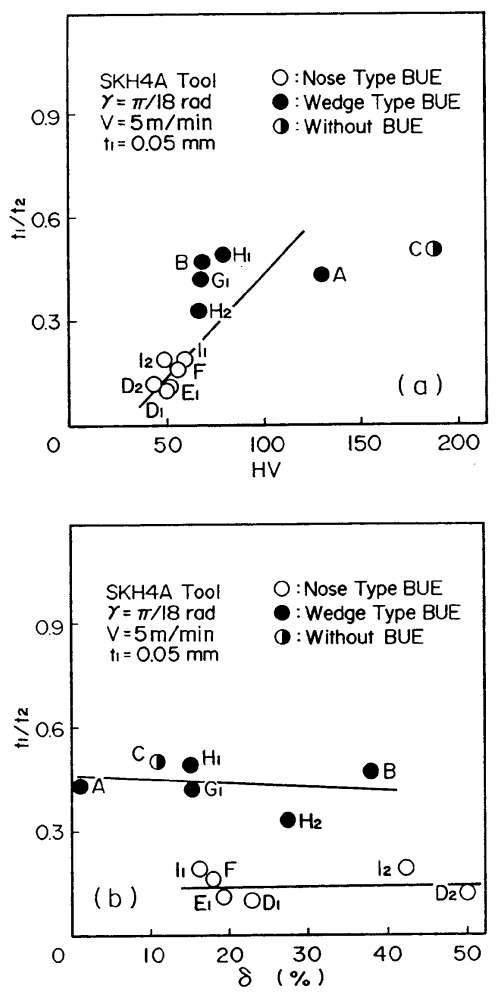

Fig. 4 Effects of mechanical properties and built-up edge on cutting ratio.

すると切りくずはその部分で切断しやすくなるものと考 えられる。

一方, 切削状態を表す指標として, 切削比 $\mathrm{t}_{1} / \mathrm{t}_{2}$ （ $\mathrm{t}_{1}$ : 切込及深さ, $\mathrm{t}_{2}$ ：切りくず厚さ）とせん断角 $\phi$ について 検討した。Fig. $4(\mathrm{a})$ は, 切削比 $\mathrm{t}_{1} / \mathrm{t}_{2}$ と被削材硬さ $\mathrm{HV}$ との関係を，また，切削比と伸び $\delta$ との関係を同図 $(\mathrm{b})$ にそれぞれ示した。図中の白丸, 黒丸はそれぞれ切削中 に生じている構成刃先の形状を示するので, 白丸が鼻 形，黒丸がくさび形である。同図(a)より，記号 C で示 される7075-T6 材は別として, 被削材硬さの大なるもの は切削比が大きくなる傾向を示し，また白丸で示される 鼻形構成刃先のグループに比べて，黒丸で示されるくさ び形構成刃先のグループの切削比は拈打むね大きくな る。一方，同図(b)より，〈さび形，鼻形構成刃先を問 わず，切削比に及ぼす被削材の伸びの影響はほとんどみ られない。

Fig. 5 は，切りくず生成の際のせん断角 $\phi$ について 調べた結果である。この場合も, せん断角と機械的性質 との相関は明確ではないが，構成刃先形状との関係で考 察すれば, くさび形構成刃先生成時のせん断角は比較的 大きく，鼻形ではそれが小さくなる傾向が認められた。 

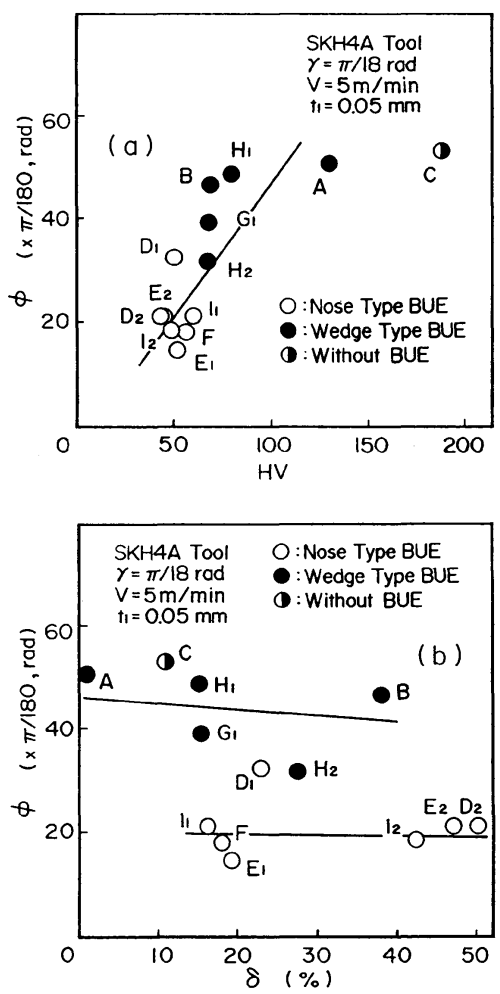

Fig. 5 Effects of mechanical properties and built-up edge on shear angle.

このよらに構成刃先が発生すると，これが切削状態を大 きく支配するため，材料の諸性質が切削過程に及ぼす影 響を調べるためには，構成刃先の影響を除いた条件下で 検討することが必要となる。

\section{3 切削抵抗に及ぼす構成刃先の影響}

Fig. 6 は切削開始より10数秒後の，いわゆる切削抵抗 が定常状態のときの切削主分力 $\mathrm{Q}$ と被削材の硬さおよ び伸びの関係を示すものである。同図 (a)に示すよらに, 鼻形構成刃先を生じる被削材ではその硬さに大きい差が みられないにもかかわらず，切削主分力に大きい違いを 生じている。一方，同図(b)によれば，鼻形構成刃先を 生じるものの場合，伸びの大きいものほど切削主分力が 増大する傾向にある。これは刃先半径の大きい鼻形構成 刃先では切りくずとの接触長さが長く，被削材伸びの大 きいものの方が切りくず流出の際の摩擦抵抗が大きくな り，切りくず生成に際してより大きな力を必要とするこ とを示している。また同図(a)の黒丸で示した，くさび 形構成刃先および構成成先を伴わない場合（図中半黒丸 で示す7075-T6 合金)，ばらつきはあるが被削材硬さの 増加に伴って切削主分力は増加の傾向を示している。他 方, 同図(b)で, くさび形構成刃先が生ずる場合
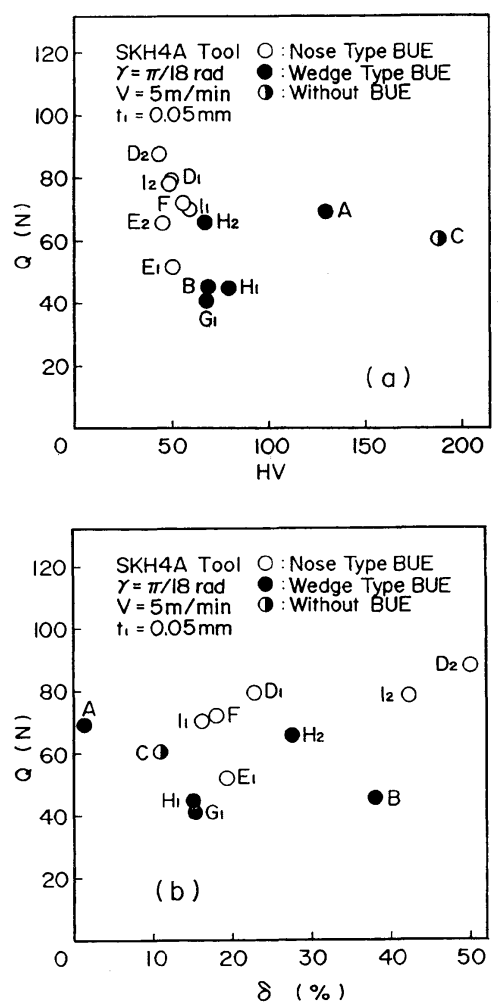

Fig. 6 Effects of mechanical properties and built-up edge on cutting force.

（7075-T6 合金を含めて）には，伸びの増加につれて切 削主分力は低下する傾向がみられる。これは，伸びの大 きい材料では硬さおよび引張強さの低下がみられ，こう した材料では切りくず生成の際のせん断抵抗が減少する ためと考えられる。以上のよらに，構成刃先が生成され る場合にはその形状が鼻形かくさび形かによって切削主 分力に対する被削材硬さおよび伸びの影響には異なった 傾向が現われることがわかった。

Fig. 7 は切削速度 Vを $200 \mathrm{~m} / \mathrm{min}$ と大きくし，構成 刃先の発生を抑制した状態での切削主分力に及ぼす被削 材の硬さおよび伸びの影響を示すものである。同図 (a) によれば，被削材の硬さが大きくなるにつれて切削主分 力は直線的に増加している。また同図(b)によれば，多 少のばらつきはみられるが，伸びの増加に伴って切削主 分力が減少する傾向を示している。このように大きい切 削速度において，切削抵抗と被削材の機械的性質との間 に相応の相関状態がみられるのは，切削点温度の上昇に よる構成刃先消隇効果によるものである6)。なお，切削 背分力については，主分力と定性的に同様の傾向であ り，結果は省略した。 

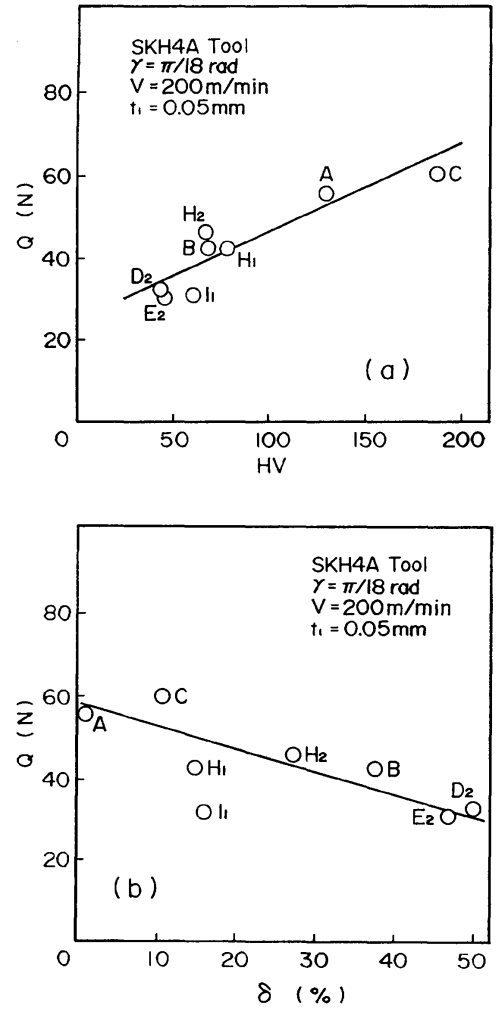

Fig. 7 Relation between cutting force and mechanical properties of work in a high speed cutting.

\section{4 切削仕上げ面粗さおよび加工変質層深さに及ぼ す構成刃先の影響}

仕上げ面粗さに及ぼす構成刃先形状の影響をみると， 鼻形構成刃先の場合，見かけ上の刃先のまるみ半径は大 となり，先に述べたように，構成刃先と切りくずの境界 が明確でないこととあわせて，仕上げ面は大きい先端半 径をもつ構成刃先による押しつけ作用と仕上げ面のむし り作用によってその粗さは大となることが考えられる。

Fig. 8 は仕上げ面粗さ $\mathrm{R}_{\mathrm{z}}$ と被削材硬さとの関係を示 するのであるが，鼻形構成刃先の場合，粗さは全般に大 となっている。一方，〈さび形構成刃先の場合，すくい 角増大の効果で，切りくず流出が滑らかに行われ，大き いむしりの発生もみられず，粗さは比較的小さくなる傾 向がみられた。また，仕上げ面粗さを材料の機械的性質 との関係より考察すると，より硬さの高い材料において 粗さは小となっているが, この傾向は, 被削材硬さが高 い領域でくさび形の構成刃先が発生することに対応して 起こったものと考えられる。被削材硬さがある值以上で は粗さはほとんど変化がみられないことから，硬さが低 く，鼻形構成刃先の生成が容易な材料域に掞いて粗さが

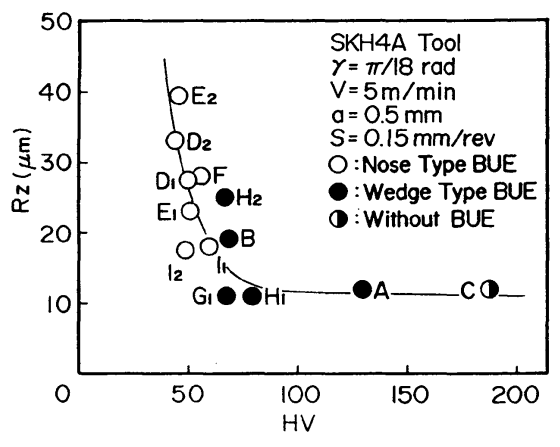

Fig. 8 Effects of work hardness and built-up edge on surface roughness.

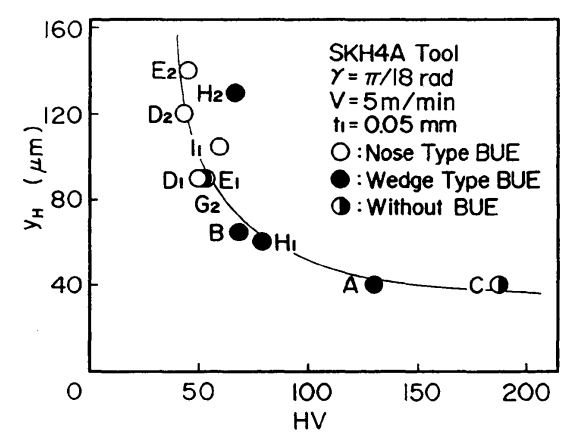

Fig. 9 Effects of work hardness and built-up edge on depth of work hardened layer.

大きく変動することが知られる。また，ここでは図示し なかったが，伸びの増加によって粗さはやや増大する傾 向を示すものの，伸びと仕上げ面粗さの相関は硬さと粗 さの場合ほど明瞭ではなかった。

切削等の機械加工が行われた仕上げ面直下には，工具 の接触と移動に伴う表面層の流動と加工硬化を生じるこ とが知られている7)。

Fig. 9 は, マイクロビッカース硬さの変化より求めた 加工硬化層深さ $\mathrm{y}_{\mathrm{H}}$ と被削材硬さとの関係を示すもので ある。加工硬化層深さと構成刃先形状の関係をみると， 加工硬化層の深さはせん断領域に拈いて，刃先から弾塑 性境界までの長さに関係し，この刃先から弾塑性境界ま での長さが工具の刃先半径に比例すること息を慮する と，鼻形構成刃先を生じる場合には硬化層深さは大とな る。他方，〈さび形構成刃先の場合には刃先半径が小さ く，したがって加工硬化層深さも小となることが考えら れる。また，アルミニウム合金の切削による加工硬化層 深さは, 鋼類の切削の場合と同様, 塑性流動層深さに比 ベて1.5〜2 倍程度深いところまで及んでいることもわ かった。 


\section{4. 結言}

各種アルミニウム合金を切削し, 構成刃先の形状に及 济す被削材の化学組成扣よび機械的性質の影響と切削過 程に及ぼす構成刃先の影響を実験的に検討した。その結 果,

（1）構成刃先形状は大別して鼻形とくさび形とに分け られるが，その違いに及ぼす化学組成の影響として，マ グネシゥムの添加によってくさび形，シリコンあるいは ビスマスの添加によって鼻形の構成刃先が生成される傾 向がみられた。

（2）構成刃先形状は，被削材の硬さおよび加工硬化性 によっても変化し，硬さが高く，加工硬化性の強い材料 ではくさび形となり，これとは逆の場合に鼻形の構成刃 先が生成される。
（3）切削中に発生する構成刃先形状の違いは，切削過 程に大きく影響し，〈さび形構成刃先が発生すると, 鼻 形の場合に比べて切削抵抗，仕上げ面粗さおよび加工変 質層深さ等が減少傾向を示すことが明らかとなった。

\section{参 考 文 献}

1）栗原健助：軽金属，36（1986）, 168 .

2）岡庭 茂, 矢部正浩, 川崎啓一郎, 水谷秀行：軽金 属, 36 (1986)，470

3）星 光一，星鐵太郎：金属切削技術，工業調査会， (1969), 26.

4）星 光一，金属切削，工業調査会，(1960), 25

5）中山一雄: 精密機械, 38, (1972), 1070.

6）財満鎮雄，八木博行，服部 聡：日本金属学会誌, 41 (1977), 956.

7）臼井英治：切削 - 研削加工学上, 共立出版, (1978), 208.

8）井川直哉：機械の研究，24（1972）. 1545. 